\title{
Antiulcerogenic activity of the extracts of Struthanthus marginatus
}

\author{
Sônia M. de F. Freire, ${ }^{1,2}$ Karla N. de S. Andrade, ${ }^{2}$ Gilvan A. \\ Aragão Jr, Elda P. Noronha, ${ }^{2}$ Selma do N. Silva, ${ }^{1,2}$ Maria do \\ Socorro de S. Cartágenes, ${ }^{2}$ Marilene O. R. Borges, ${ }^{2}$ Maria Nilce \\ de S. Ribeiro, ${ }^{3}$ Luce M. B. Torres, ${ }^{4}$ Antônio C. R. Borges ${ }^{*}, 1,2$
}

${ }^{\text {I} P r o g r a m a ~ d e ~ P o ́ s-g r a d u a c ̧ a ̃ o ~ e m ~ B i o t e c n o l o g i a ~-~ R e n o r b i o, ~ U n i v e r s i d a d e ~ F e d e r a l ~ d o ~}$ Maranhão, Brazil,

${ }^{2}$ Laboratório de Farmacologia, Departamento de Ciências Fisiológicas, Universidade Federal do Maranhão, Brazil,

${ }^{3}$ Laboratório de Farmacognosia, Departamento de Farmácia, Universidade Federal do Maranhão, Brazil,

${ }^{4}$ Instituto de Botânica de São Paulo, Secretaria do Meio Ambiente do Estado de São Paulo, Brazil.

\begin{abstract}
The gastroprotective action of the aqueous extract (AE) and the hydroalcoholic extract obtained from the leaves of Struthanthus marginatus (Desr.) Blume, Loranthaceae, were performed with in vivo models in rodents using: ethanol, indomethacin or stress-induced ulcers, determination of gastric secretion and the mucus production. The scavenger activity of AE in vitro was tested by the DPPH method. The treatment with the extracts $(125-1000 \mathrm{mg} / \mathrm{kg})$ significantly inhibited ulcerative lesions in comparison with the negative control groups in all the models evaluated and demonstrated greater effectiveness of the aqueous extract. Regarding the model of gastric secretion, a reduction in volume of gastric juice and total acidity was observed, as well as an increase in the gastric $\mathrm{pH}$. The treatment of rats raised the gastric mucus production. Significant DPPH scavenging activity was evident in the AE. No sign of toxicity was observed. These results show that $S$. marginatus possesses gastroprotective activity. There are indications that the mechanisms involved in anti-ulcer activity are related to a decrease in acid secretion and an increase in gastric mucus content. Also, there is evidence for the involvement of antioxidant activity in the gastroprotective mechanism.
\end{abstract}

Revista Brasileira de Farmacognosia Brazilian Journal of Pharmacognosy 21(6): 1089-1095, Nov./Dec. 2011
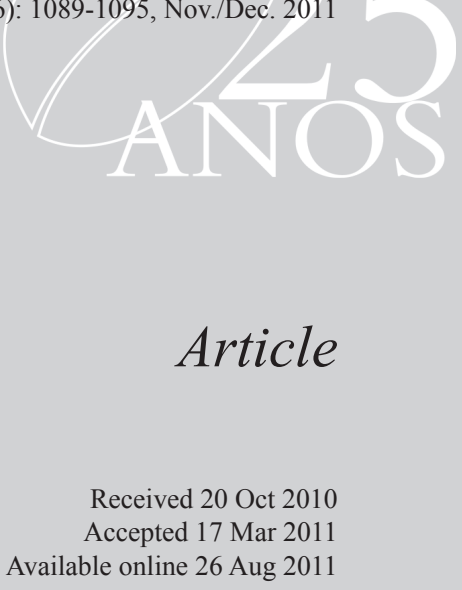

Available online 26 Aug 2011

Keywords:

antiulcer activity

erva-de-passarinho

gastroprotection

Struthanthus marginatus

ISSN 0102-695X http://dx.doi.org/10.1590/S0102$695 \times 2011005000150$

\section{Introduction}

Peptic ulcer is one of the most common gastrointestinal problems seen in clinical practice. While its pathophysiology is complex, there is a consensus among the great majority of authors that the lesion results from an imbalance between aggressive factors (gastric acid secretion, alcohol consumption, nonsteroidal antiinflammatory drugs, smoking, and Helicobacter pylori infection) and the defensive function of the mucosa (secretion of mucus, bicarbonate, prostaglandins, blood flow and epidermal growth factors). Emotional stress and the production of reactive oxygen species are also factors that can influence the development of lesions in the digestive mucosa (Das \& Banerjee, 1993; Chan \& Leung, 2002; Kwiecien et al., 2002).

Struthanthus marginatus (Desr.) Blume is a parasitic plant, popularly known as "erva-de- passarinho", together with other species of the Loranthaceae family (Correa, 1984). In the state of Maranhão, northern Brazil, it is recommended for stomach ailments. Other popular uses include disorders of respiration (bronchitis and hemoptysis) and leucorrhea (Brandão et al., 2009).

There are only few scientific studies that refer $S$. marginatus. The species contains high levels of trace elements, including silicon, manganese, iron, copper and zinc, and such a composition may explain the use of the plant for wound healing, since the biochemical processes involved in wound healing depend on enzyme activity that relies, in turn, on the presence of trace elements (Pereira \& Felcman, 1998). On the other hand, the literature does contain references to the biological activity of other species of the Struthanthus genus. For example, the ethanolic extract of the aerial parts of $S$. orbicularis has been shown to neutralize the effect of the venom of Bothropus asper in mice (Nuñez 
et al., 2004). In other work, rutin extracted from $S$. subtilis exhibited cytotoxic activity in four human tumor cell lines (HEp-2, MCF-7, MKN-45, HT-29) (Cordero et al., 2003). The antimicrobial activity of $S$. vulgaris was demonstrated with a $70 \%$ hydroalcoholic extract of dried leaves and fractions obtained from the same extract, tested against samples of Gram positive and Gram negative bacteria (Vieira et al., 2005). Meanwhile, results reported by Lorenzana-Jiménez et al. (2006) suggested a potential hypotensive effect of the methanolic extract of leaves of $S$. venetus in anesthetized rats.

Considering that peptic ulcer is a multifactorial condition, and that important determining factors include damage to the mucosa by ethanol, the use of nonsteroidal antiinflammatory agent, and the occurrence of stress, the objective of this study was to determine the antiulcerogenic potential of extracts of the leaves of S. marginatus.

\section{Material and Methods}

\section{Plant material}

Leaves of Struthanthus marginatus (Desr.) Blume, Loranthaceae, were collected from São Jose de Ribamar, Maranhão, Brazil, between August and October 2006. The plant was authenticated by Dra. Marie Sugiyama from Instituto de Botânica, São PauloSP, Brazil. A specimen of the plant was deposited in the Herbarium "Maria Eneyda P. Kauffman Fidalgo" of this institution under voucher number 397.724.

\section{Preparation of the extracts}

The leaves of the plant were dried at room temperature $\left(35-37{ }^{\circ} \mathrm{C}\right)$ and ground. The aqueous extract (AE) was prepared by infusion of the leaves 72 ${ }^{\circ} \mathrm{C}$ for $30 \mathrm{~min}$. The infusion was filtered, concentrated under vacuum (at $55 \circ \mathrm{C}$ ) and freeze-dried (yield 26\%). The hydroalcoholic extract (HAE) was prepared by maceration of the leaf powder in $70 \%$ ethanol, with replacement of the solvent every $72 \mathrm{~h}$. The solvent was concentrated under vacuum (at $55^{\circ} \mathrm{C}$ ) providing a yield of $42.6 \%$.

\section{Phytochemical screening}

A phytochemical analysis of extracts for the detection of various classes, such as anthocyanins, anthocyanidins, flavones, flavonols, xanthones, chalcones, flavanonols, leucoanthocyanidins, flavanones, catechins, tannins hydrolysable, tannins condensable, phenols, steroids, triterpenes and alkaloids was carried out according to standard procedures
(Matos, 1997).

Detection of radical scavenging compounds by DPPH method

The AE $(400 \mu \mathrm{g})$ was tested for its antioxidant activity (AA) starting with a thin layer chromatography (TLC) screening, using upper phase of mixture of n-buthanol: acetic acid and water (BAW) (40:10:50). After the chromatograms were sprayed with a $0.2 \%$ methanol $(80 \%)$ solution of the free radical 2 , 2-difenil-1-picrilhidrazil (DPPH). The DPPH reagent was detected as yellow spots on a violet background. The quantification of the antioxidant activity of the aqueous extract (AE) was accessed on the basis of radical scavenging effect of DPPH solution $(0.006 \%$ $\mathrm{w} / \mathrm{v})$. Different dilutions of the extract amounting to $2.0 \mathrm{~mL}$ were added to $1.0 \mathrm{~mL}$ of DPPH solution. These solution mixtures were kept in dark for $30 \mathrm{~min}$ and optical density was measured at $517 \mathrm{~nm}$ using SP2000 UV Spectrophotometer. All determinations were performed in duplicate (Guimarães et al., 2010).

\section{Animals}

Wistar rats (160-220 g) and Swiss mice (20-32 g) of either sex were obtained from the Animal House of Universidade Federal do Maranhão, for use in the experiments. The animals were allowed at least three days for acclimatization to the animal room conditions $\left(24{ }^{\circ} \mathrm{C}\right)$ before experiments and were maintained on a standard pellet diet and water ad libitum. Food was withdrawn 12-16 $\mathrm{h}$ before the experiment, but animals were allowed free access to water. For each group 5 or 6 animals were used. All experiments followed a protocol approved by the Committee for Ethics in Animal Experimentation of the Universidade Estadual do Maranhão, Brazil (Protocol number 879/2008) in accordance with the Federal Government legislation on animal care.

\section{Evaluation of acute toxicity}

The acute toxicity studies were performed in male and female Swiss albino mice ( $n=5$ per sex). A single dose of AE or HAE $(5 \mathrm{~g} / \mathrm{kg}$ ) was administered orally (p.o.) to groups of animals, which were fasted for $12 \mathrm{~h}$ prior the administration. Animals receiving water served as control. The mice were observed for signs and symptoms associated with the extracts administration at $0,5,10,20,30,60,120,240$ and 480 min after and then once a day for the next fourteen days and any changes in behavior or manifestations of toxic symptoms. 


\section{Anti-ulcer study}

Fasted rats were treated with AE or HAE (125$1000 \mathrm{mg} / \mathrm{kg}$ ), the standard antiulcer drug omeprazole $(20 \mathrm{mg} / \mathrm{kg}$ ) or water (vehicle, $10 \mathrm{~mL} / \mathrm{kg}$, p.o., $\mathrm{n}=6$ ). Gastric lesions were induced after $1 \mathrm{~h}$ by $75 \%$ ethanol (0.25 mL/100 g, p.o.), according to Robert et al. (1979) or indomethacin $(10 \mathrm{mg} / \mathrm{kg}$, s.c.), according to Rao et al. (1997) or stress (cold restraint at $4{ }^{\circ} \mathrm{C}$ for $2 \mathrm{~h}$ ), according to Tariq et al. (1987). The animals were sacrificed 1 or $6 \mathrm{~h}$ after treatments with ethanol or indomethacin, respectively, and immediately after the stress exposure. The stomachs were removed and the mucosa washed and examined under a stereoscope to score the number of ulcers and to determine the ulcer index (UI) according to Vela et al. (1997).

\section{Acid secretory parameters study}

Pyloric ligation was performed in rats under light anesthesia according to Shay et al. (1945). The $\mathrm{AE}$ or HAE (250-1000 $\mathrm{mg} / \mathrm{kg})$, omeprazole (20 $\mathrm{mg} / \mathrm{kg}$ ) or water (vehicle, $10 \mathrm{~mL} / \mathrm{kg}$ ), was injected intraduodenally (i.d.). The animals were sacrificed 4 $\mathrm{h}$ after, the stomach was dissected out and the gastric secretion collected $(n=6)$. The mucosal surface of the stomach was washed with $2 \mathrm{~mL}$ of distilled water and the final volume and $\mathrm{pH}$ were measured. Total acidity was determined by titrating with $0.1 \mathrm{~N}$ sodium hydroxide using phenolphthalein as indicator.

\section{Gastric mucus study}

The method described by Corner et al. (1974) was employed, with modifications. Fasted rats were treated with AE or HAE (250-1000 mg/kg), misoprostol $(100 \mu \mathrm{g} / \mathrm{kg}$ ) or water (vehicle, $10 \mathrm{~mL} / \mathrm{kg}$, p.o., $\mathrm{n}=6)$. The animals were sacrificed $1 \mathrm{~h}$ after the treatment and half of the stomachs were immediately transferred to $0.1 \%$ Alcian blue solution in $0.16 \mathrm{mM}$ sucrose and 50 $\mathrm{mM}$ sodium acetate $(\mathrm{pH} 5.8)$. After $2 \mathrm{~h}$ the segments were rinsed twice with $250 \mathrm{mM}$ sucrose solution for 15 and $45 \mathrm{~min}$, and the dye complexed with the gastric mucus was extracted with $500 \mathrm{mM}$ magnesium chloride solution shaken intermittently for $2 \mathrm{~h}$. The extract was mixed with $5 \mathrm{~mL}$ of diethyl ether and centrifuged at 3600 rpm for $10 \mathrm{~min}$, and the amount of Alcian blue in the aqueous phase was determined spectrophotometrically at $598 \mathrm{~nm}$.

\section{Intestinal motility in mice}

Mice were treated with AE and HAE (500 and $1000 \mathrm{mg} / \mathrm{kg})$, scopolamine $(200 \mathrm{mg} / \mathrm{kg})$ or vehicle (water $0.1 \mathrm{~mL} / 10 \mathrm{~g}$, p.o., $\mathrm{n}=6$ ), $60 \mathrm{~min}$. prior to the administration of a $5 \%$ charcoal suspension in $1 \%$ guar gum $(0.1 \mathrm{~mL} / 10 \mathrm{~g}$ body weight, p.o.). After 30 min, the animals were killed by cervical dislocation and their stomachs and small intestines were removed. The distance traveled by the charcoal plug from the pylorus to the cecum was measured and expressed as a percentage of the total intestinal length (Carlini et al., 2010; Rao et al., 1997).

\section{Statistical analysis}

Results were expressed as mean \pm SEM Significant differences between the treated groups and the control were determined by ANOVA and Newman-Keuls multiple comparison test. The degree of significance was set at $p<0.05$.

\section{Results}

\section{Phytochemical screening}

The phytochemical screening determined the presence of alkaloids, triterpenes and catechins on HAE only. Tannins hydrolysable are on two extracts. Flavanonols and flavanones are present in higher proportions on AE. The procedures were negative for the rest of the classes.

\section{Antioxidant activity of $A E$}

The preliminary qualitative determination of antioxidant activity of AE by TLC on silica gel with BAW (40:10:50, upper phase) revealed $0.4 \mathrm{mmol} / \mathrm{L}$ of DPPH radical, suggesting the existence of substances with antioxidant activity, as evidenced by the presence of yellow spots on the purple background, resulting from reduction of the DPPH radical with retention factor $\mathrm{Rf}=0.89$ to $\mathrm{AE}$ and 0.97 to quercetin. The AE was effective at scavenging free radicals at all concentrations tested (Table 1).

Table 1. Values of antioxidant activity (\%AA) of the aqueous extract (AE) of Struthanthus marginatus and the standard (quercetin).

\begin{tabular}{ccc}
\hline $\begin{array}{c}\text { Concentration } \\
\mu \mathrm{g} / \mathrm{mL}\end{array}$ & $\begin{array}{c}\text { Quercetin } \\
(\% \mathrm{AA})\end{array}$ & $\begin{array}{c}\mathrm{AE} \\
(\% \mathrm{AA})\end{array}$ \\
\hline 0.5 & $82.58 \pm 1.33$ & $76.58 \pm 2.03$ \\
2.0 & $86.50 \pm 3.06$ & $82.75 \pm 2.91$ \\
10.0 & $87.64 \pm 1.79$ & $86.53 \pm 4.54$ \\
\hline
\end{tabular}

\section{Toxicological results}

For the toxicity evaluation, a single dose $(5 \mathrm{~g} / \mathrm{kg}$, 
p.o.) of the extracts was administered to animals. During the observation period after the administration the animals were all in good condition, we did not observe any sedation or other behavioral changes and there was no significant difference between the weights of treated animals and the controls. At autopsy, no significant change or lesion was observed in the viscera of any animal.

Effect of extracts on gastric lesions induced by ethanol or indomethacin or stress

The pretreatment of the animals with both extracts decreased gastric lesions induced by ethanol. The extent of inhibitions for the respective doses employed (AE or HAE 125,250 and $500 \mathrm{mg} / \mathrm{kg}$ ) was $65.4,86$ and $91 \%$ or 29.5, 41.3 and 58.4\%. The AE $(125,250$ and $500 \mathrm{mg} / \mathrm{kg})$ exhibited a protective effect against indomethacin-induced gastric lesions and the extent of inhibition for the respective doses employed, compared to vehicle group, was 55.4, 76.2 and $68.4 \%$. Against indomethacin-induced ulceration the HAE protected only at higher doses $(500$ and $1000 \mathrm{mg} /$ $\mathrm{kg}$ ), with a decrease of 57.6 and $68.1 \%$ in gastric lesion scores, respectively. The pretreatment of the animals with AE $(125,250$ and $500 \mathrm{mg} / \mathrm{kg})$ or HAE $(250,500$ and 1000 $\mathrm{mg} / \mathrm{kg}$ ) also decreased the gastric lesions induced by stress reducing the lesions by $36.4,60.7$ and $61 \%$ or $47.8,54.8$ and $64 \%$, respectively. Omeprazole, the positive control included in the study also offered significant protection in every model (Table 2).

Table 2. Effects of aqueous extract (AE), hydroalcoholic extract (HAE) of Struthanthus marginatus and omeprazole (p.o.) on gastric lesions in rats.

\begin{tabular}{cccc}
\hline \multirow{2}{*}{$\begin{array}{c}\text { Treatment } \\
(\mathrm{mg} / \mathrm{kg})\end{array}$} & \multicolumn{3}{c}{ Gastric lesions } \\
\cline { 2 - 4 } & Ethanol 75\% & Indomethacin & Stress \\
\cline { 2 - 4 } & \multicolumn{3}{c}{ Ulcer index } \\
\hline Vehicle & $2.3 \pm 15.5$ & $55.4 \pm 8.5$ & $27.2 \pm 2.0$ \\
Omeprazole 20 & $* 41.1 \pm 9.2$ & $* 9.0 \pm 1,1$ & $* 11.0 \pm 1.5$ \\
AE 125 & $* 31.9 \pm 8.1$ & $* 24.7 \pm 4.4$ & $* 17.3 \pm 2.7$ \\
AE 250 & $* 12.9 \pm 2.9$ & $* 13.2 \pm 3.4$ & $* 10.7 \pm 2.2$ \\
AE 500 & $* 8.3 \pm 0.6$ & $* 17.5 \pm 3.7$ & $* 10.6 \pm 1.6$ \\
HAE 125 & $65.1 \pm 5.7$ & - & - \\
HAE 250 & $* 54.2 \pm 7.8$ & $39.3 \pm 6.9$ & $* 14.2 \pm 3.1$ \\
HAE 500 & $* 38.4 \pm 7.0$ & $* 23.5 \pm 3.5$ & $* 12.3 \pm 1.8$ \\
HAE 1000 & - & $* 17.7 \pm 4.9$ & $* 9.8 \pm 0.9$ \\
\hline
\end{tabular}

The results are expressed as mean \pm S.E.M, $\mathrm{n}=5-6 . * p<0.05$ versus control (ANOVA, followed by Newman-Keuls multiple comparison test).

\section{Effect of extracts on gastric secretion}

The effects of extracts on gastric secretion are shown in Table 3 . Control rats with $4 \mathrm{~h}$ pylorus ligation produced $6 \pm 0.3 \mathrm{~mL}$ of secretion with a $\mathrm{pH}$ of $2.03 \pm 0.28$ and a total acidity of $0.27 \pm 0.06 \mathrm{mEq}\left[\mathrm{H}^{+}\right] / \mathrm{L} / 4 \mathrm{~h}$. Secretion was reduced with administration of $\mathrm{AE}(1000 \mathrm{mg} / \mathrm{kg})$ by $39 \%$, and with HAE (250 to $1000 \mathrm{mg} / \mathrm{kg}$ ) by $36.8,44.9$ and $37.6 \%$, respectively. Treatment with AE $(500 \mathrm{mg} /$ $\mathrm{kg})$ or HAE $(1000 \mathrm{mg} / \mathrm{kg})$ raised the $\mathrm{pH}$ by 2.03 and 2.09 units, respectively. Treatment with AE $(1000 \mathrm{mg} / \mathrm{kg})$ or HAE $(500 \mathrm{mg} / \mathrm{kg})$ also reduced total acidity by 70.4 and $74.1 \%$, respectively.

Table 3. Effect of aqueous extract (AE), hydroalcoholic extract (HAE) of Struthanthus marginatus and omeprazole on gastric secretion of $4 \mathrm{~h}$ pylorus-ligated rats.

\begin{tabular}{cccc}
\hline Treatment (id) & $\begin{array}{c}\text { Volume } \\
(\mathrm{mL})\end{array}$ & $\mathrm{pH}$ & $\begin{array}{c}\text { Total } \\
\text { acidity mEq } \\
{\left[\mathrm{H}^{+}\right] / \mathrm{L} / 4 \mathrm{~h}}\end{array}$ \\
\hline Control & $6.0 \pm 0.3$ & $2.0 \pm 0.3$ & $0.27 \pm 0.06$ \\
Omeprazole $20 \mathrm{mg} / \mathrm{kg}$ & $3.3 \pm 0.5^{*}$ & $5.7 \pm 0.3^{*}$ & $0.04 \pm 0.01^{*}$ \\
AE $250 \mathrm{mg} / \mathrm{kg}$ & $5.0 \pm 0.6$ & $3.0 \pm 0.4$ & $0.18 \pm 0.04$ \\
AE $500 \mathrm{mg} / \mathrm{kg}$ & $5.3 \pm 0.6$ & $4.1 \pm 0.5^{*}$ & $0.25 \pm 0.03$ \\
AE $1000 \mathrm{mg} / \mathrm{kg}$ & $3.6 \pm 0.5^{*}$ & $3.6 \pm 0.2^{*}$ & $0.08 \pm 0.01^{*}$ \\
$\mathrm{HAE} 250 \mathrm{mg} / \mathrm{kg}$ & $3.8 \pm 0.4^{*}$ & $3.9 \pm 0.6^{*}$ & $0.14 \pm 0.03$ \\
$\mathrm{HAE} 500 \mathrm{mg} / \mathrm{kg}$ & $3.3 \pm 0.2^{*}$ & $3.4 \pm 0.4$ & $0.07 \pm 0.01^{*}$ \\
$\mathrm{HAE} 1000 \mathrm{mg} / \mathrm{kg}$ & $3.7 \pm 0.4^{*}$ & $4.1 \pm 0.6^{*}$ & $0.16 \pm 0.04$ \\
\hline
\end{tabular}

The results are expressed as mean \pm S.E.M, $\mathrm{n}=6 .{ }^{*} p<0.05$ versus control (ANOVA, followed by Newman-Keuls multiple comparison test).

\section{Effect of extracts on gastric mucus}

The highest dose tested of AE or HAE (1000 $\mathrm{mg} / \mathrm{kg}$ ) raised the gastric mucus production by 80.5 and $93.6 \%$, respectively (control $11.2 \pm 0.6 \mu \mathrm{g}$ of Alcian blue/g of tissue). Misoprostol, the positive control included, significantly raised the amount of gastric mucus, by $99.7 \%$ (Table 4).

Table 4. Effect of aqueous extract (AE), hydroalcoholic extract (HAE) of Struthanthus marginatus and misoprostol on mucus amount in rats.

\begin{tabular}{cccc}
\hline $\begin{array}{c}\text { Treatment } \\
(\text { p.o. })\end{array}$ & Dose $/ \mathrm{kg}$ & $\begin{array}{c}\text { Alcian blue } \\
\mu \mathrm{g} / \mathrm{g} \text { of tissue }\end{array}$ & Increase (\%) \\
\hline Control & - & $11.2 \pm 0.6$ & - \\
Misoprostol & $100 \mu \mathrm{g}$ & $22.3 \pm 2.6$ & $99.7 \%^{*}$ \\
$\mathrm{AE}$ & $250 \mathrm{mg}$ & $14.2 \pm 3.3$ & $27.4 \%$ \\
$\mathrm{AE}$ & $500 \mathrm{mg}$ & $13.8 \pm 0.4$ & $23.8 \%$ \\
$\mathrm{AE}$ & $1000 \mathrm{mg}$ & $20.2 \pm 2.3$ & $80.5 \%^{*}$ \\
$\mathrm{HAE}$ & $250 \mathrm{mg}$ & $15.4 \pm 1.5$ & $38.0 \%$ \\
HAE & $500 \mathrm{mg}$ & $13.1 \pm 0.8$ & $17.0 \%$ \\
HAE & $1000 \mathrm{mg}$ & $21.7 \pm 3.7$ & $93.6 \% *$ \\
\hline
\end{tabular}

The results are expressed as mean \pm S.E.M, $\mathrm{n}=6 .{ }^{*} p<0.05$ versus control (ANOVA, followed by Newman-Keuls multiple comparison test).

\section{Effect of extracts on intestinal transit in mice}


The pretreatment of mice with AE or HAE (500 and $1000 \mathrm{mg} / \mathrm{kg}$, p.o.) did not alter the charcoal intestinal transit (control 56.6 $\pm 2.4 \%$ ). Scopolamine $(200 \mathrm{mg} / \mathrm{kg}$, p.o.), the positive control, reduced this parameter by $53.4 \%$.

\section{Discussion}

The results of this study show, in acute models of gastric ulceration induced by a necrotizing agent (ethanol), inhibition of the biosynthesis of prostaglandin (indomethacin) and maintaining the animal in a cold environment (stress), that the oral administration of extracts of the plant Struthanthus marginatus provides protection against gastric lesions induced by all the ulcerogenic agents employed. However, we observed a difference in relation to the effectiveness of the aqueous and hydroalcoholic extracts. In the model of ethanol-induced ulceration, when the same doses of the two extracts were used $(125-500 \mathrm{mg} / \mathrm{kg})$ there were clear differences in relation to the UI, which was 2.0 to 4.6 times higher in the animals treated with the HAE. When ulceration was induced by indomethacin the reduction in the ulcerogenic index in the rats treated with the $\mathrm{AE}(500 \mathrm{mg} / \mathrm{kg})$ was $68 \%$, the same as that in the animals that received the HAE $(1000 \mathrm{mg} / \mathrm{kg})$, even though the dose of the latter was twice that of the former, emphasizing the greater effectiveness of the AE in relation to the HAE. With regard to the model of stress-induced ulceration the doses employed of the EA, which reduced the ulcerogenic index by a statistically significant amount, were half of the HAE doses. Thus, the AE showed itself to be more effective compared to the HAE in all of the models studied, something which may be explained by the composition of the extracts since the phytochemical screening demonstrated greater proportions of flavononols and flavanones in the AE, despite the existence of hydrolysable tannins in equal proportions in the two extracts.

The presence of these compounds in plant extracts has suggested antiulcerogenic activity in various studies. For example, flavonoids are compounds reported to have gastroprotective activity in experimental models of gastric ulceration (Baggio et al., 2007; Gurbuz et al., 2009; Zduníc et al., 2009). Tannins, followed by flavonoids, are the main components of the methanolic extract of Mouriri elliptica, a plant with gastroprotective activity (Moleiro et al., 2009).

We determined the activity of the extracts against the production of gastric secretion. The extracts of $S$. marginatus reduced in vivo the volume and the acidity of gastric secretion. In our analysis of the AE we found that the assessment parameters for gastric secretion were reduced with double the dose required for a reduction in the UI (that is, $1000 \mathrm{mg} / \mathrm{kg} \mathrm{AE}$ reduced the volume of gastric secretion by $38 \%$ and the total acidity by $70 \%$ ). Meanwhile, the three doses of the HAE (250 to $1000 \mathrm{mg} / \mathrm{kg}$ ) significantly reduced the volume of gastric secretion, as well as affecting the acidity, with the $\mathrm{pH}$ increasing by 1.89 and 2.1 when HAE was administered at the doses of $250 \mathrm{mg}$ / $\mathrm{kg}$ and $1000 \mathrm{mg} / \mathrm{kg}$, respectively. Considering that acid secretion is an important aggressor in the mucosa, an increase in $\mathrm{pH}$ and a reduction of total acidity induced by the plant extracts may constitute part of the process of mucosal protection afforded by the extracts (Jain et al., 2007, Massignani et al., 2009).

Our experiments also showed that the extracts of $S$. marginatus $(1000 \mathrm{mg} / \mathrm{kg})$ increased the production of mucus, indicating that the protective effect of the plant itself may be related, in part, to this activity, since the production of mucus is an important factor in the defense of the gastrointestinal mucosa against ulcerogenic agents (Werther, 2000; Laine et al., 2008).

The AE of $S$. marginatus was found to be more effective antiulcerogenic agent, then we chose to examine its activity as a scavenger of free radicals. The in vitro test carried out by means of the reaction with DPPH showed that the AE possesses significant antioxidant activity, something which also could contribute to the protective effect of the extract on the gastric mucosa (Berenguer et al., 2006, Galati et al., 2003, Potrich et al., 2010).

This effect was not accompanied by a change in intestinal transit, thereby eliminating a possible anticholinergic or adrenergic effect.

Any toxicity for the extracts of $S$. marginatus was detected, a result which justifies further research into the antiulcerogenic activity of the plant indicated by its popular use.

Taken together these results demonstrate gastroprotective activity in the extracts of leaves of $S$. marginatus, probably brought about through a decrease in gastric secretion, stimulation of mucus production as well as the antioxidant activity of the extract. Such results justify the popular use of this plant for gastric disturbances and contribute to its pharmacological validation, thereby indicating the plant's phytotherapeutic potential. Studies are underway to identify the active compound and to further clarify its mechanism of action.

\section{Acknowledgements}

Acknowledgments to FAPEMA (Process APP - 00705/09) and CNPQ (Process 555140/2010) for financial support. We are also thankful to Dra. Marie Sugiyama for the identification of the plant and to Aceilton Aquino for the suggestion ethnobotany. 


\section{References}

Baggio CH, Freitas CS, Otofuji GM, Cipriani TR, Souza LM, Sassaki GL, Iacomini M, Marques MCA, Mesia-Vela S 2007. Flavonoid-rich fraction of Maytenus ilicifolia Mart. ex. Reiss protects the gastric mucosa of rodents through inhibition of both $\mathrm{H}^{+}, \mathrm{K}^{+}$-ATPase activity and formation of nitric oxide. J Ethnopharmacol 181: 433-440.

Berenguer B, Sánchez LM, Quílez A, López-Barreiro M, Haro O, Gálvez J, Martín MJ 2006. Protective and antioxidant effects of Rhizophora mangle L. against NSAID-induced gastric ulcers. J Ethnopharmacol 103: 194-200.

Brandão MGL, Cosenza GP, Grael CFF, Netto Junior NL, Monte-Mór RLM 2009. Traditional uses of American plant species from the $1^{\text {st }}$ edition of Brazilian Official Pharmacopoeia. Rev Bras Farmacogn 19: 478-487.

Carlini EA, Duarte-Almeida JM, Rodrigues E, Tabach R 2010. Antiulcer effect of the pepper trees Schinus terebinthifolius Raddi (aroeira-da-praia) and Myracrodruon urundeuva Allemão, Anacardiaceae (aroeira-do-sertão). Rev Bras Farmacogn 20: 140146.

Chan FK, Leung WK 2002. Peptic ulcer disease. Lancet 360: 933-941.

Cordero CP, Pinzon R, Aristizabal FA 2003. Cytotoxicity of bixin, rutin, pinitol $\mathrm{B}$ and ent-16-kauren-19-oic acid isolated from Colombian plants. Rev Col Cienc Quím Farm 32: 137-140.

Corner SJ, Morrissey SM, Woods RJ 1974. A method for the quantitative estimation of gastric barrier mucus. $J$ Physiol 242: 116-117.

Corrêa MP 1984. Dicionário de Plantas úteis do Brasil e das Exóticas Cultivadas, vol. IV. Imprensa Nacional: Rio de Janeiro.

Das D, Banerjee RK 1993. Effect of stress on the anti-oxidant enzymes and gastric ulceration. Mol Cell Biochem 125: $115-125$

Galati EM, Mondelo MR, Giuffrida D, Dugo G, Miceli N, Pergolizzi S, Taviano MF 2003. Chemical characterization and biological effects of sicilian Opuntia ficus indica (L.) Mill. fruit juice: antioxidant and antiulcerogenic Activity. J Agr Food Chem 51: 4903-4908.

Guimarães RN, Truitt MCT, Bersani-Amado CA, Formagio ASN, Cardoso FP, Costa WF, Souza MC, Sarragiotto MH 2010. Free radical scavenging and anti-edematogenic activities of Paullinia elegans Cambess., Sapindaceae, leaves extracts. Rev Bras Farmacogn 20: 113-116.

Gurbuz I, Yesilada E, Ito S 2009. An anti-ulcerogenic flavonol diglucoside from Equisetum palustre L. $J$ Ethnopharmacol 121: 360-65.

Jain KS, Shah A.K, Bariwal J, Shelke SM, Kale AP, Jagtap JR, Bhosale AV 2007. Recent advances in proton pump inhibitors and management of acid-peptic disorders. Bioorgan Med Chem 15: 1181-1205.

Kwiecien S, Brzozowski T, Konturek SJ 2002. Effects of reactive oxygen species action on gastric mucosa in various models of mucosal injury. $J$ Physiol
Pharmacol. 53: 39-50.

Laine L, Takeuchi K, Tarnawsk A 2008. Gastric mucosal defense and cytoprotection: Bench to Bedside. Gastroenterology 135: 41-60.

Lorenzana-Jiménez M, Guerrero GAM, González XG, Granados EG, Cassani J 2006. Phytochemical and pharmacological preliminary study of the methanolic extract from Struthanthus venetus in cardiovascular system of anestethized rat. Pharmacologyonline 3: 359-364.

Massignani JJ, Lemos M, Maistro EL, Schaphauser HP, Jorge RF, Sousa JPB, Bastos JK, Andrade SF 2009. Antiulcerogenic activity of the essential oil of Baccharis dracunculifolia on different experimental models in rats. Phytother Res 23: 1355-1360.

Matos FJA 1997. Introdução a Fitoquímica Experimental, $2^{\text {th }}$ ed. UFC Edições: Fortaleza.

Moleiro FC, Andreo MA, Santos RC, Moraes TM, Rodrigues CM, Carli CBA, Lopes FCM, Pellizzon CH, Carlos IZ, Bauab TM, Vilegas W, Hiruma-Lima CA 2009. Mouriri elliptica: Validation of gastroprotective, healing and anti-Helicobacter pylori effects. $J$ Ethnopharmacol 123: 359-368.

Nuñez V, Otero R, Barona J, Saldarriaga M, Osorio RG, Fonnegra R, Jimenez SL, Diaz A, Quintana JC 2004. Neutralization of the edema forming, defibrination and coagulant effects of Bothropus asper venom by extracts of plants used by healers in Colombia. Braz J Med Biol Res 37: 969-977.

Pereira CEB, Felcman J 1998. Correlation between five minerals and the healing effect of brazilian medicinal plants. Biol Trace Elem Res 65: 251-259.

Potrich FB, Allemand A, Silva LM, Santos AC, Baggio $\mathrm{CH}$, Freitas CS, Mendes DAGB, Andre E, Werner MFP, Marques MCA 2010. Antiulcerogenic activity of hydroalcoholic extract of Achillea millefolium L.: Involvement of the antioxidant system. $J$ Ethnopharmacol 130: 85-92.

Rao VSN, Santos FA, Sobreira TT, Souza MF, Melo CL, Silveira ER 1997. Investigations on the gastroprotective and antidiarrhoeal properties of ternatin, a tetramethoxyflavone from Egletes viscosa. Planta Med 63: 146-149.

Robert A, Nezamis JE, Lancaster C, Hauchar AJ 1979. Cytoprotection by prostaglandins in rats. Prevention of gastric necrosis produced by alcohol, $\mathrm{HCl}, \mathrm{NaOH}$, hypertonic $\mathrm{NaCl}$ and thermal injury. Gastroenterology 77: 433-443.

Shay H, Komarov SA, Fels D, Meranze D, Gruenstein M, Siplet H 1945. A simple method for the uniform production of gastric ulceration in the rats. Gastroenterology 5: 43-61.

Tariq M, Parmar NS, Agoel AM 1987. Gastric antisecretory, gastric and duodenal antiulcer and cytoprotective properties of proglumide in rats. J Pharmacol Exp Ther 241: 602-607.

Vela SM, Souccar C, Lima-Landman MT, Lapa AJ 1997. Inhibition of gastric acid secretion by the aqueous extract and purified extracts of Stachytarpheta cayennensis. Planta Med. 63: 36-39.

Vieira OMC, Santos MH, Silva GH, Siqueira AM 2005. 
Atividade antimicrobiana de Struthanthus vulgaris (erva-de-passarinho). Rev Bras Farmacogno 15: 145 154.

Werther JL 2000. The gastric mucosal barrier. Mt Sinai J Med 67: 41-53.

Zduníc G, Godevac D, Milenkovíc M, Vucícevíc D, Šavikin K, Menkovíc N, Petrovíc S 2009. Evaluation of Hypericum perforatum oil extracts for an antiinflammatory and gastroprotective activity in rats. Phytother Res 23: 1559-1564.

\section{*Correspondence}

Antônio C. R. Borges

Departamento de Farmácia, Universidade Federal do Maranhão

Av. dos Portugueses, s/n, Campus do Bacanga, 65085-580

São Luis-MA, Brazil

romao@ufma.br, romao.borges@pq.cnpq.br

Tel:+55 9833018533

Fax:+55 9833018004 